\title{
RISK ASSESSMENT IN PREGNANCY AMONG WOMEN AGED OVER FORTY
}

\author{
Ana-Meyra Potkonjak ${ }^{1}$, Ivka Djaković ${ }^{1}$, Senka Sabolović Rudman ${ }^{1}$, Lara Poljak $^{2}$ and Vesna Košec ${ }^{1}$ \\ ${ }^{1}$ Department of Gynecology and Obstetrics, Sestre milosrdnice University Hospital Centre, Zagreb, Croatia; \\ ${ }^{2}$ School of Dental Medicine, University of Zagreb, Zagreb, Croatia
}

\begin{abstract}
SUMMARY - The objective of this study was to assess the relationship between women's age and risk of pregnancy-related complications. The study was a retrospective cohort analysis of the pregnancy-related complications and outcomes between two age groups of parturient women. Categorical data were expressed as absolute and relative frequencies. Statistical analysis was performed using $\chi^{2}$-test. The incidence of gestational diabetes was higher in the 40-47 age group as compared with the 20-24 age group. The rates of hypertension, preeclampsia, intrahepatic cholestasis of pregnancy and hypothyroidism did not differ between the two groups. The rates of labor induction, oxytocin use, vaginal delivery, and need for episiotomy were higher in younger age group. Dystocia and breech presentation as indications for cesarean section were more common among younger women. According to study results, the risk of gestational diabetes and rates of cesarean delivery increased with advanced maternal age.
\end{abstract}

Key words: Maternal age; Pregnancy; Risk factors; Delivery

\section{Introduction}

Similar to western countries, an increasing number of pregnancies among women over 40 years of age has also been recorded in Croatia. These findings can be attributed to life conditions, socioeconomic circumstances, and a high rate of success of in vitro fertilization methods. According to the Croatian Institute of Public Health, in 2017, there were 3.4\% of parturient women aged $40-44$ and $0.16 \%$ over age $45^{1}$. Birth rate among women aged 40-44 was 8.7/1000 deliveries in 2016 and 9/1000 deliveries in 2017 $17^{1,2}$. The EUROSTAT report also ranks Croatia higher in comparison to other countries with high rates of older parturient women ${ }^{3}$. This study evaluated the relationship between women's age and risk of pregnancy-related complications in a tertiary-care hospital during a period of one year.

Correspondence to: Ana-Meyra Potkonjak, MD, Department of Obstetrics and Gynecology, Sestre milosrdnice University Hospital Centre, Vinogradska c. 29, HR-10000 Zagreb, Croatia

E-mail: ampotkonjak@gmail.com

Received December 31, 2019, accepted May 11, 2021

\section{Subjects and Methods}

This retrospective cohort analysis evaluated pregnancy outcomes in two age groups of parturient women, i.e. 20-24 and 40-47 years of age. The study was conducted on a sample of 362 postpartum women at the Department of Gynecology and Obstetrics, Sestre milosrdnice University Hospital Centre in 2017. Patient data were retrieved from hospital records. The study was approved by the institutional Ethics Committee.

Study participants were selected according to their age. Advanced maternal age is defined as maternal age above 35 , very advanced maternal age as age above 40 , and extremely advanced maternal age as age above 45 years at childbirth ${ }^{4}$.

Considering the rising trend of childbearing at or above the age of 40 and the potential adverse outcomes, we investigated pregnancies of mothers older than 40 and compared them to the group of women aged $20-24^{5}$. The women having given birth in 2017, aged 20-24 and 40-47 were included. All singleton pregnancies over 22 weeks of gestation were analyzed. During that period, no cases of stillborn were recorded 
at our Department. Exclusion criteria were history of multiple pregnancies and pregnancies that ended before the $22^{\text {nd }}$ week.

The following data were retrieved: maternal age, parity, health status, and pregnancy associated conditions such as gestational diabetes, preeclampsia and hypertensive disorders, intrahepatic cholestasis in pregnancy, hypothyroidism, incidence of nutritional and respiratory placental insufficiency, need for labor induction or expectant management, mode of delivery, need for instrumental or operative delivery, gestational age at birth, and birth weight. The diagnosis of gestational diabetes was based on the International Association of Diabetes and Pregnancy Study Group criteria $^{6}$. Gestational hypertension and preeclampsia were defined according to the American College of Obstetricians and Gynecologists criteria ${ }^{7}$.

Clinical guideline issued by the Society for Maternal-Fetal Medicine was used to diagnose intrahepatic cholestasis in pregnancy ${ }^{8}$. The diagnosis of thyroid dysfunction was based on the American Thyroid Association guidelines ${ }^{8}$. Categorical data were expressed as absolute and relative frequencies. Statistical analysis was performed using the $\chi^{2}$-test. Statistical Package for Social Sciences (SPSS v. 19) was used on statistical analysis.

\section{Results}

The study included 362 women, i.e. 118 (32.6\%) in the $40-47$ age group and $244(67.4 \%)$ in the $20-24$ age group. The incidence of gestational diabetes was $38.1 \%$ in the 40-47 age group, compared with $26.2 \%$ in the 20-24 age group, yielding a statistically significant difference $\left(\chi^{2}=5.358 ; p<0.05\right)$. The rate of hypertension, preeclampsia, cholestasis and hypothyroidism did not differ between the two groups. Labor induction rate was higher in the $20-24$ age group (35.2\% vs. 12.7\%), yielding a statistically significant difference $\left(\chi^{2}=20.077\right.$; $\mathrm{p}<0.01)$. The rate of oxytocin use also was significantly higher in the younger group $(58.6 \%$ vs. $46.6 \%$; $\left.\chi^{2}=4.619 ; \mathrm{p}<0.05\right)$. Similarly, the rate of vaginal delivery was higher in the younger age group, with a statistically significant difference $\left(\chi^{2}=13.540, \mathrm{p}<0.05\right)$, and so was the rate of episiotomy $\left(\chi^{2}=15.297 ; p<0.01\right)$. The rates of cervical rupture, vaginal and perineal tear did not differ between the groups. The rate of cesarean section was higher in the $40-47$ age group $\left(\chi^{2}=5.358\right.$;

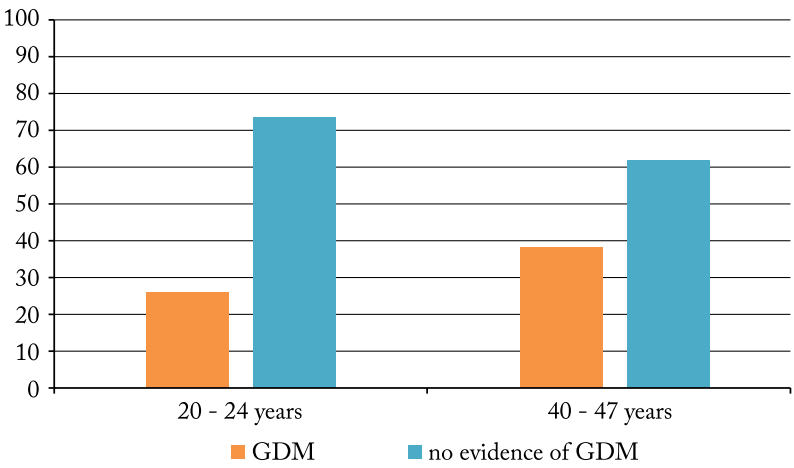

Fig. 1. Incidence of gestational diabetes (GDM) in two age groups $\left(\chi^{2}=5.358\right.$; $\left.p<0.05\right)$.

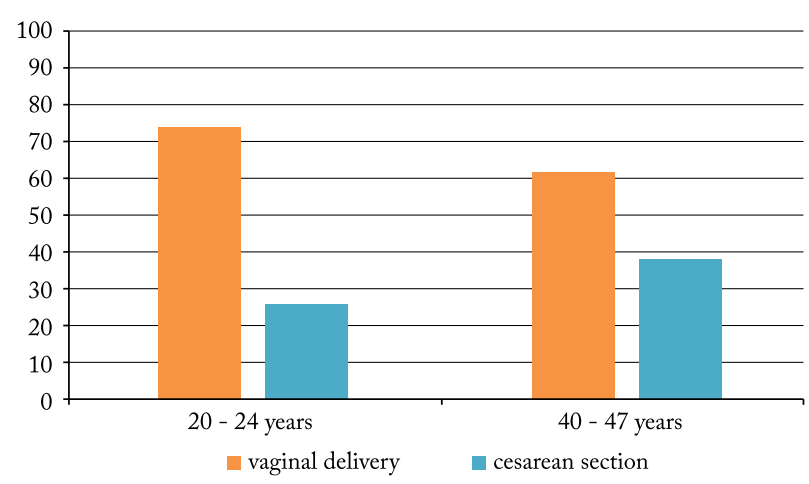

Fig. 2. The rate of vaginal delivery was higher in younger age group with a statistically significant difference $\left(\chi^{2}=13.540 ; p<0.05\right)$.

$\mathrm{p}<0.05)$. Dystocia as an indication for cesarean section was more common in the 20-24 age group $\left(\chi^{2}=11.086\right.$; $\mathrm{p}<0.01)$, just like breech presentation $\left(\chi^{2}=7.908\right.$ : $\mathrm{p}<0.01)$. The rate of respiratory or nutritive placental insufficiency and intrauterine asphyxia did not differ between the groups.

\section{Discussion}

Recently, the number of pregnancies at an advanced maternal age is increasing ${ }^{9}$, which has led to an increased number of studies assessing adverse effects of advanced maternal age on pregnancy outcomes. Although an increased risk of undesirable outcome has been reported in older pregnant women, there still are controversies about this relationship ${ }^{10,11}$. The main problems are definition of pregnancy outcome and heterogeneity of study groups.

It is known that insulin sensitivity decreases with age due to deterioration of beta cell function. In this 
context, our study showed a significantly higher incidence of gestational diabetes in the group of older women. These results are consistent with those reported by Shan et al. who found two to three times higher incidence of gestational diabetes among women with advanced age ${ }^{12}$. Some other studies confirmed these results ${ }^{13,14}$. A meta-analysis conducted by $\mathrm{Li}$ et al. revealed the risk of gestational diabetes to rise linearly with maternal age ${ }^{15}$. As stated in the literature, the increased risk of gestational diabetes due to advanced maternal age can been demonstrated after adjustment for additional factors such as obesity and parity ${ }^{16}$. To demonstrate this, maternal age over 35 years increases the risk of gestational diabetes three times, while obese women are five times more likely to develop gestational diabetes ${ }^{16}$. Additionally, ethnic differences influence the risk of gestational diabetes. Thus, an increased risk of gestational diabetes is found in Asian women compared to European women ${ }^{15}$.

The reported results on the increased risk of other pregnancy associated conditions such as gestational hypertension and preeclampsia, ${ }^{9,10}$ in relation to advanced maternal age were not confirmed in our study. So far, the increased risk of developing hypertensive disorders in pregnancy with increasing maternal age has been attributed to oxidative stress and decreased levels of nitric oxide with negative effect on endothelium relaxation ${ }^{17}$. Compared with the group of pregnant women younger than 30 , the risk of developing hypertension in pregnancy is 1.2 and 1.6 times higher in mothers aged 35-39.9 and 40-44.9, respectively. The risk of developing preeclampsia increases by $4 \%$ with every year after the age of $32^{18}$. Recently, hemodynamic changes and myocardial remodeling process in pregnancy have been largely investigated, with introduction of some new biochemical markers for potential quantification of myocardial damage in pregnant $\mathrm{pa}^{-}$ tients with hypertensive disorders ${ }^{19-23}$. These markers may have a role in elucidating pathogenetic mechanisms of hypertensive disorders in both young and older pregnant patients.

Nevertheless, Kahveci et al. published a paper on a higher incidence of hypertension in pregnant women over 35 years of age ${ }^{24}$. Similar results are reported by Duckitt and Harrington, who found the risk of preeclampsia to be twice as likely at age over $40^{11,25}$. Cleary-Goldman et al. did not find any association between maternal age and gestational hypertension ${ }^{26}$, which could be the result of better antenatal care and awareness of risks associated with advanced age.

Analyzing a total of 25,054 pregnancies, Claramonte Nieto et al. did not find any significant differences in the incidence of intrahepatic cholestasis of pregnancy (ICP) between pregnant patients younger than 30 and those older than $40^{27}$. In a Chinese study investigating 12,200 pregnancies, the incidence of ICP was $6.06 \%$. Results showed that the incidence of ICP increased with advancing maternal age if women were 30 years of age or older. The incidence of ICP decreased with increasing maternal age in women younger than $30^{28}$. In this study, the rate of ICP did not differ between the two groups.

Besides gestational diabetes, thyroid dysfunction is another common pregnancy related endocrine disorder accompanied by both maternal and fetal complications. The levels of thyroid stimulating hormone increase with age ${ }^{29}$, whereas maternal age over 30 is considered to be a risk factor for hypothyroidism, which was the only documented type of thyroid dysfunction in our study population. However, the incidence of hypothyroidism did not differ between the two groups in our study.

Induction of labor is often performed to reduce negative maternal and/or fetal outcomes, for indications in which expectant management of pregnancies poses a higher risk of adverse perinatal outcomes than induced birth. In seeking to address the effect of induction of labor at 40 weeks of gestation on perinatal mortality in women aged 35 or older, Knight et al. found that induction of labor was associated with a $66 \%$ lower risk of perinatal death than expectant management ${ }^{30}$. Surprisingly, we found a significantly higher incidence of induction of labor in younger group of parturient women and therefore a higher rate of oxytocin use, as expected.

According to the World Health Organization recommendation published in 2018, evidence for episiotomy rates, derived from a Cochrane systematic review, highlights rates of $8 \%$ to $59 \%$ (median $32 \%$ ) in the selective episiotomy groups ${ }^{31}$. This wide range of incidence could be attributed to different obstetric practices in hospital institutions. This survey found a higher incidence of episiotomy in younger groups of pregnant women. This result can be explained by the higher incidence of labor induction among younger women. 
Cesarean section is one of the most commonly investigated pregnancy outcomes. According to current publications, the rate of this type of obstetric intervention is increased among pregnant women of advanced age. However, evidence for indications for cesarean delivery in a group of women of advanced age is insufficient. The parity, maternal pre-existing health conditions, and obstetric complications are considered as the main confounding factors in the analysis of this relationship. Final decision on the mode of delivery (vaginal delivery vs. elective cesarean section) among parturient women at advanced age in our institution is often facilitated by examining indications of obstetric and non-obstetric conditions and the accompanying aspects of advanced maternal age.

However, there are some conflicting data on this approach. Lavecchia et al. found a significantly higher incidence of maternal morbidity in the advanced maternal age group of previously healthy women who had elective cesarean section when compared with delivery outcome in women of the same age group with vaginal delivery $^{32}$. In the abovementioned study, elective cesarean section was connected with a higher risk of cardiac arrest, acute renal failure, peripartum hysterectomy, and sepsis ${ }^{32}$.

Nevertheless, there is a justifiable active approach in term pregnancies in the advanced maternal age group, but a systematic review did not reveal a significant effect on the cesarean section rates in advanced age women ${ }^{33}$. Some studies showed a two-fold likelihood of cesarean section in both nulliparous and multiparous advanced age women ${ }^{34-36}$. Explanation for this may be found in physiological changes of the myometrium and reduction of oxytocin receptors with age, resulting in ineffective labor contractions. Often subjective aspects of advanced maternal age to an obstetrician can lead to early decision on cesarean section ${ }^{36}$. In contrast to most studies ${ }^{37}$, where dystocia was more likely in the advanced age group and is considered to be an independent risk factor, we found a higher incidence of dystocia in the group of younger women. The reason for these results was our common practice of elective cesarean section in the advanced age group in order to avoid dystocia. Unlike most studies ${ }^{38}$, we also found that breech presentation was more likely in younger women who had cesarean section. Some differences in the results could be due to heterogeneity of the study population.
Pregnancy in advanced maternal age is high-risk pregnancy and therefore deserves special attention and closer obstetric follow up, as well as cooperation with the pregnant women. However, pregnant women of younger age also manifested some significant obstetric conditions that should not be overlooked. Diversity of results of the investigated groups and studies suggest that results must be analyzed with caution.

\section{References}

1. Rodin U, Draušnik Ž, Cerovečki I, Jezdić D. Childbirths in healthcare institutions in Croatia in 2017 [Internet]. Hrvatski zavod za javno zdravstvo [cited 2019 Nov 05]. Available from: https://www.hzjz.hr/wp-content/uploads/2018/07/Porodi_2017.pdf

2. Rodin U, Draušnik Ž, Cerovečki I. Childbirths in healthcare institutions in Croatia in 2016 [Internet]. Hrvatski zavod za javno zdravstvo [cited 2019 Nov 05]. Available from: https:// www.hzjz.hr/wp-content/uploads/2017/08/Porodi_2016.pdf

3. Eurostat. Total fertility rate and age of women at birth of first child (2018) [Internet]. 2020. Available from: https://ec.europa.eu/eurostat/statistics-explained/index.php/Fertility_statistics\#Total_fertility_rate_and_age_of_women_at_birth_of_ first_child

4. Lean SC, Derricott H, Jones RL, Heazell AEP. Advanced maternal age and adverse pregnancy outcomes: a systematic review and meta-analysis. PLoS One. 2017;12(10):1-15. DOI: 10.1371/journal.pone.0186287

5. Frederiksen LE, Ernst A, Brix N, Lauridsen LLB, Roos L, Ramlau-Hansen $\mathrm{CH}$, et al. Risk of adverse pregnancy outcomes at advanced maternal age. Obstet Gynecol. 2018;131 (3):457-63. DOI: 10.1097/AOG.0000000000002504

6. Group THSCR. Hyperglycemia and adverse pregnancy outcomes. N Engl J Med. 2008;358:1991-2002. DOI: 10.1056/ NEJMoa0707943

7. Hypertension G. ACOG Practice Bulletin No. 202: Gestational Hypertension and Preeclampsia. Obstet Gynecol. 2019; 133(1):e1-25. DOI: 10.1097/AOG.0000000000003018

8. American Thyroid Association statement on early maternal thyroidal insufficiency: recognition, clinical management and research directions. Thyroid. 2005;15(1):77-9. DOI: 10.1089/ thy.2005.15.77

9. Montan S. Increased risk in the elderly parturient. Curr Opin Obstet Gynecol. 2007;19(2):110-2. DOI: 10.1097/GCO.0b $013 \mathrm{e} 3280825603$

10. Khalil A, Syngelaki A, Maiz N, Zinevich Y, Nicolaides $\mathrm{KH}$. Maternal age and adverse pregnancy outcome: a cohort study. Ultrasound Obstet Gynecol. 2013;42(6):634-43. DOI: 10.1002/uog.12494

11. Traisrisilp K, Tongsong T. Pregnancy outcomes of mothers with very advanced maternal age (40 years or more). J Med Assoc Thai. 2015;98(2):117-22. 
12. Shan D, Qiu PY, Wu YX, Chen Q, Li AL, Ramadoss S, et al. Pregnancy outcomes in women of advanced maternal age: a retrospective cohort study from China. Sci Rep. 2018;8(1):1-9. DOI: $10.1038 / \mathrm{s} 41598-018-29889-3$

13. Laopaiboon M, Lumbiganon P, Intarut N, Mori R, Ganchimeg T, Vogel JP, et al. Advanced maternal age and pregnancy outcomes: a multicountry assessment. BJOG. 2014;121 Suppl: 49-56. DOI: 10.1111/1471-0528.12659

14. Dietl A, Cupisti S, Beckmann MW, Schwab M, Zollner U. Pregnancy and obstetrical outcomes in women over 40 years of age. Geburtshilfe Frauenheilkd. 2015;75(8):827-32. DOI: 10.1055/s-0035-1546109

15. Li Y, Ren X, He L, Li J, Zhang S, Chen W. Maternal age and the risk of gestational diabetes mellitus: a systematic review and meta-analysis of over 120 million participants. Diabetes Res Clin Pract [Internet]. 2020;162:108044. Available from: https://doi.org/10.1016/j.diabres.2020.108044

16. Laine MK, Kautiainen H, Gissler M, Raina M, Aahos I, Järvinen $\mathrm{K}$, et al. Gestational diabetes in primiparous women impact of age and adiposity: a register-based cohort study. Acta Obstet Gynecol Scand. 2018;97(2):187-94. DOI: 10.1111/ aogs.13271

17. Taddei S, Virdis A, Ghiadoni L, Versari D, Salvetti A. Endothelium, aging, and hypertension. Curr Hypertens Rep. 2006;8(1):84-9.

18. Timofeev J, Reddy UM, Huang C-C, Driggers RW, Landy HJ, Laughon SK. Obstetric complications, neonatal morbidity, and indications for cesarean delivery by maternal age. Obstet Gynecol [Internet]. 2013;122:1184-95. Available from: https:// www.ncbi.nlm.nih.gov/pmc/articles/PMC3624763/pdf/nihms412728.pdf

19. Potkonjak AM, Sabolović Rudman S, Nikolac Gabaj N, Kuna $\mathrm{K}$, Košec V, Stanec Z, et al. Urinary troponin concentration as a marker of cardiac damage in pregnancies complicated with preeclampsia. Med Hypotheses 2020;144:110252. DOI: 10. 1016/j.mehy.2020.110252

20. Beigi A, Khezri A, Khezri A, Khezri M. High troponin I level among patients with severe preeclampsia. Life Sci J. 2013; 10(278):206-7.

21. Fleming SM, O'Gorman T, Finn J, Grimes H, Daly K, Morrison JJ. Cardiac troponin I in pre-eclampsia and gestational hypertension. Br J Obstet Gynaecol. 2000;107(11):1417-20. DOI: $10.1111 / \mathrm{j} .1471-0528.2000 . t b 11658 . x$

22. Melchiorre K, Sutherland GR, Baltabaeva A, Liberati M, Thilaganathan B. Maternal cardiac dysfunction and remodeling in women with preeclampsia at term. Hypertension. 2011;57(1): 85-93. DOI: 10.1161/HYPERTENSIONAHA.110.162321

23. Verlohren S, Perschel FH, Thilaganathan B, Dröge LA, Henrich W, Busjahn A, et al. Angiogenic markers and cardiovascular indices in the prediction of hypertensive disorders of pregnancy. Hypertension. 2017;69(6):1192-7. DOI: 10.1161/HYPERTENSIONAHA.117.09256

24. Kahveci B, Melekoglu R, Evruke IC, Cetin C. The effect of advanced maternal age on perinatal outcomes in nulliparous singleton pregnancies. BMC Pregnancy Childbirth. 2018;18 (1):1-7. DOI: $10.1186 / \mathrm{s} 12884-018-1984-x$

25. Duckitt K, Harrington D. Risk factors for pre-eclampsia at antenatal booking: systematic review of controlled studies. $\mathrm{Br}$ Med J. 2005;330(7491):565-7. DOI: 10.1136/bmj.38380. 674340.E0

26. Cleary-Goldman J, Malone FD, Vidaver J, Ball RH, Nyberg DA, Comstock CH, et al. Impact of maternal age on obstetric outcome. Obstet Gynecol. 2005;105(5):983-90. DOI: 10.1097 /01.AOG.0000158118.75532.51

27. Claramonte Nieto M, Meler Barrabes E, Garcia Martínez S, Gutiérrez Prat M, Serra Zantop B. Impact of aging on obstetric outcomes: defining advanced maternal age in Barcelona. BMC Pregnancy Childbirth. 2019;19(1):1-10. DOI: 10.1186/ s12884-019-2415-3

28. Gao XX, Ye MY, Liu Y, Li JY, Li L, Chen W, et al. Prevalence and risk factors of intrahepatic cholestasis of pregnancy in a Chinese population. Sci Rep. 2020;10(1):1-7. DOI: 10.1038/ s41598-020-73378-5

29. Dülek H. The prevalance of thyroid dysfunction and relationship with perinatal outcomes in third trimester pregnants who apply to tertiary center. North Clin Istanb. 2018;6(3):267-72. DOI: $10.14744 /$ nci.2018.51422

30. Knight HE, Cromwell DA, Gurol-Urganci I, Harron K, van der Meulen JH, Smith GCS. Perinatal mortality associated with induction of labour versus expectant management in nulliparous women aged 35 years or over: an English national cohort study. PLoS Med. 2017;14(11):1-14. DOI: 10.1371/journal.pmed.1002425

31. World Health Organization. Intrapartum care for a positive childbirth experience [Internet]. 2018. 212 p. Available from: http://apps.who.int/iris/bitstream/10665/260178/1/9789241 550215-eng.pdf?ua=1\%0Ahttp://www.who.int/reproductivehealth/publications/intrapartum-care-guidelines/en/

32. Lavecchia M, Sabbah M, Abenhaim HA. Effect of planned mode of delivery in women with advanced maternal age. Matern Child Health J. 2016;20(11):2318-27. DOI: 10.1007/ s10995-016-2055-4

33. Walker KF, Malin G, Wilson P, Thornton JG. Induction of labour versus expectant management at term by subgroups of maternal age: an individual patient data meta-analysis. Eur J Obstet Gynecol Reprod Biol [Internet]. 2016;197:1-5. Available from: http://dx.doi.org/10.1016/j.ejogrb.2015.11.004

34. Dunn L, Kumar S, Beckmann M. Maternal age is a risk factor for caesarean section following induction of labour. Aust N Z J Obstet Gynaecol.2017;57(4):426-31. DOI: 10.1111/ajo.12611

35. Bayrampour H, Heaman M. Advanced maternal age and the risk of cesarean birth: a systematic review. Birth. 2010;37(3): 219-26. DOI: 10.1111/j.1523-536X.2010.00409.x

36. Rosenthal AN, Paterson-Brown S. Is there an incremental rise in the risk of obstetric intervention with increasing maternal age? BJOG. 1998;105(10):1064-9. DOI: 10.1111/j.14710528.1998.tb09937.x 
37. Waldenström U, Ekéus C. Risk of labor dystocia increases with maternal age irrespective of parity: a population-based register study. Acta Obstet Gynecol Scand. 2017;96(9):1063-9. DOI: 10.1111/aogs.13167
38. Bin YS, Roberts CL, Nicholl MC, Nassar N, Ford JB. Contribution of changing risk factors to the trend in breech presentation at term. Aust N Z J Obstet Gynaecol. 2016;56(6):564-70. DOI: 10.1111/ajo.12556

Sažetak

\section{PROCJENA RIZIKA UTRUDNOĆAMA MAJKI U DOBI IZNAD 40 GODINA}

\section{A-M. Potkonjak, I. Djakovic, S. Sabolović Rudman, L. Poljak i V. Košec}

Cilj istraživanja bio je ispitati povezanost dobi majke i rizika povezanih s njihovim trudnoćama. Retrospektivno kohortno istraživanje provedeno je usporedbom pojavnosti rizika i ishoda trudnoća dviju skupina trudnica. Kategorijski podatci prikazani su apsolutnim i relativnim frekvencijama. Statistička analiza provedena je primjenom $\chi^{2}$-testa. Incidencija gestacijskog dijabetesa bila je veća u skupini trudnica u dobi od 40-47 godina u usporedbi sa skupinom u dobi od 20-24 godine. Stopa hipertenzije, preeklampsije, intrahepatične kolestaze u trudnoći i hipotireoidizma nije se razlikovala između dviju dobnih skupina trudnica. Stope indukcije porođaja, upotrebe oksitocina, vaginalnog porođaja i potreba za epiziotomijom bile su veće u trudnica mlađe dobi. Nenapredovanje porođaja i stav ploda zatkom kao indikacije za carski rez bile su češće u žena mlađe dobi. Rezultati istraživanja upućuju na veći rizik gestacijskog dijabetesa i dovršenja trudnoće carskim rezom u trudnica uznapredovale životne dobi.

Ključne riječi: Majčina dob; Trudnoća; Čimbenici rizika; Porođaj 